\title{
KEANEKARAGAMAN JENIS BURUNG DI KEBUN CAMPURAN
}

\author{
Diversity of Bird in Mixed Garden \\ Hadinoto $^{1}$, Eni Suhesti ${ }^{1}$ \\ ${ }^{1}$ Staf Pengajar Fakultas Kehutanan Universitas Lancang Kuning \\ Jln. Yos Sudarso Km. 8 Rumbai Pekanbaru Riau Telp./Fax. (0761) 54092 \\ E-mail:hadinoto@unilak.ac.id,suhestieni@unilak.ac.id
}

Diterima: 18 Januari 2021, Direvisi: 21 Januari 2021, Disetujui: 01 Februari 2021

DOI: $10.31849 /$ forestra.v16i1.5864

\begin{abstract}
Birds are one of the ecosystem components that have an important role in supporting the life cycle of organisms. The research objectives were to calculate the diversity of bird species and identify sources of bird feed in mixed gardens. Bird data were analyzed using Species Diversity Index, Species Richness Index, Species Abundance Index, dominance analysis, bird distribution analysis and species encounter level analysis, for vegetation analyzed based on the type and part eaten by the birds. In the mixed garden of Pandau Jaya Village, 27 species of birds were found consisting of 15 families. The types of birds that were frequently present were the Cucak Kutilang (Pycnonotus aurigaster) with 44 individuals and the Perkutut Jawa (Geopelia striata) with 37 individuals. Bird species diversity ( $H^{\prime}$ ) in mixed gardens was relatively moderate with a value of 2.90, the Evenness Index (E) of 0.88 and the Reachennes Index $(R)$ of 4.40. Vegetation types as a source of food: Mahogany, Jengkol, Jackfruit, Jambu Air, Acacia mangium, Rubber, Matoa, Salam, Angsana, Mango, Breadfruit, Rambutan, Longan, Starfruit, Sengon, Kersen, Lamtoro, Beringin, Ketapang, Mahang, Palm Oil, Coconut, Areca, Palm, Cassava, Sweet Potatoes, Corn, Taro, Eggplant, Chili, Tekokak, Lengkuas, Sugarcane, Long Beans, Banana, Papaya, Flowers. Grasses
\end{abstract}

Keywords: birds; mixed gardens; vegetation

\begin{abstract}
ABSTRAK
Burung merupakan salah satu komponen ekosistem yang memiliki peranan penting dalam mendukung berlangsungnya siklus kehidupan organisme. Tujuan penelitian adalah menghitung keanekaragaman jenis burung dan mengidentifikasi sumber pakan burung di kebun campuran. Data burung dianalisis dengan menggunakan Indeks Keanekaragaman Jenis, Indeks Kekayaan Jenis, Indeks Kelimpahan Jenis, analisis dominansi, analisis penyebaran burung dan analisis tingkat pertemuan jenis, untuk vegetasi dianalisis berdasar pada jenis dan bagian yang dimakan burung. Pada Kebun Campuran Desa Pandau Jaya, ditemukan 27 jenis burung terdiri atas 15 famili. Jenis burung yang sering hadir adalah Cucak Kutilang (Pycnonotus aurigaster) sebanyak 44 individu dan Perkutut Jawa (Geopelia striata) 37 individu. Keanekaragaman jenis burung $\left(\mathrm{H}^{\prime}\right)$ pada kebun campuran relatif sedang dengan nilai 2,90, Indeks Kemerataan (E) sebesar 0,88 dan Indeks Kekayaan (R) sebesar 4,40. Jenis vegetasi sebagai sumber pakan : Mahoni, Jengkol, Nangka, Jambu Air, Akasia mangium, Karet, Matoa, Salam,
\end{abstract}


Angsana, Mangga, Sukun, Rambutan, Lengkeng, Belimbing, Sengon, Kersen, Lamtoro, Beringin, Ketapang, Mahang, Kelapa Sawit, Kelapa, Pinang, Palem-paleman, Ubi Kayu, Ubi Rambat, Jagung, Talas, Terong, Cabe, Tekokak, Lengkuas, Tebu, Kacang Panjang, Pisang, Pepaya, Bunga-bungaan. Rumput-rumputan.

Kata kunci : burung; kebun campuran; vegetasi

\section{PENDAHULUAN}

Burung merupakan salah satu komponen ekosistem yang memiliki peranan penting dalam mendukung berlangsungnya suatu siklus kehidupan organisme. Keadaan ini dapat dilihat dari rantai makanan dan jaring-jaring kehidupan yang membentuk sistem kehidupannya dengan komponen ekosistem lainnya seperti tumbuhan dan serangga. Oleh karena itu keberadaan burung di suatu kawasan sangatlah penting, karena dapat mempengaruhi keberadaan dan persebaran jenis tumbuhan.

Burung merupakan satwa liar yang mudah ditemukan hampir pada setiap lingkungan bervegetasi. Habitatnya dapat mencakup berbagai tipe ekosistem, mulai dari ekosistem alami sampai ekosistem buatan. Penyebaran yang luas tersebut menjadikan burung sebagai salah satu sumber kekayaan hayati Indonesia yang potensial. Di samping berperan dalam keseimbangan ekosistem burung dapat menjadi indikator perubahan lingkungan.
Desa Pandau Jaya merupakan salah satu desa di Kecamatan Siak Hulu Kabupaten Kampar yang saat ini sedang berkembang dengan pesat baik dalam pembangunan sarana dan prasarana maupun peningkatan jumlah penduduk. Perkembangan Kecamatan Siak Hulu ikut berpengaruh terhadap perkembangan kawasan sekitarnya sebagai daerah pengembangan. Hal tersebut tentu akan berdampak bagi ketersediaan ruang terbuka hijau atau lahan yang dapat dijadikan sebagai habitat burung menjadi semakin sedikit. Berkurangnya ruang terbuka hijau di daerah perbatasan dikhawatirkan akan menyebabkan berkurangnya hidupan liar yang ada, salah satunya adalah burung. Menurut Warsito dan Bismark (2009) keberadaan suatu spesies di suatu tempat tergantung dari adanya sumber pakan dan kondisi habitat yang sesuai. Lingkungan yang berubah akan akan mengakibatkan perubahan kondisi ekologis yang ditandai dengan menurunnya potensi 
keanekaragaman hayati, khususnya satwa liar (Nandika 2005).

Alikodra (2002) menyatakan bahwa tingginya keanekaragaman jenis burung di suatu wilayah didukung oleh tingginya keanekaragaman habitat karena habitat bagi satwa liar secara umum berfungsi sebagai tempat untuk mencari makan, minum, istirahat, dan berkembang biak. Berdasar pada fungsi tersebut, maka keanekaragaman jenis burung juga berkaitan erat dengan keanekaragaman tipe habitat serta beragamnya fungsi dari setiap tipe habitat yang ada di wilayah pedesaan. Kelestarian burung dapat dipertahankan dengan melakukan konservasi jenis yang didahului dengan berbagai studi atau penelitian tentang satwa tersebut, antara lain mengenai populasi, habitat dan lingkungan yang mempengaruhinya. Wilayah pedesaan tidak hanya berfungsi sebagai tempat tinggal manusia tetapi juga sebagai salah satu tempat bagi burung untuk mencari makan/habiat pada vegetasi yang ada, terutama kebun campuran yang ada di desa. Dengan keanekaragaman jenis tumbuhan yang ada, wilayah pedesaan diharapkan dapat mendukung kehidupan berbagai jenis burung. Upaya untuk melindungi dan melestarikan terhadap jenis-jenis burung di suatu kawasan, termasuk di Desa Pandau Jaya Kecamatan Siak Hulu Kabupaten Kampar dapat dilakukan dengan adanya data dan informasi awal tentang burung tersebut, yaitu: seberapa besar keanekaragaman jenis burung yang ada dan bagaimana keberadaan vegetasi sebagai tempat burung untuk beraktifitas yang ada di wilayah pedesaan.

\section{Tujuan Penelitian}

Tujuan penelitian ini adalah : mengidentifikasi keanekaragaman jenis burung di kebun campuran; mengidentifikasi sumber pakan burung yang ada di kebun campuran

\section{Manfaat Penelitian}

Penelitian ini diharapkan dapat memberikan manfaat sebagai sumber informasi pendukung pelestarian kekayaan jenis burung yang terdapat di kebun campuran di wilayah perkotaan dan bahan pertimbangan untuk pengembangan pembangunan daerah dengan tetap memperhatikan fungsi ekologi. 


\section{METODE PENELITIAN}

\section{Tempat dan Waktu}

Penelitian ini dilakukan di Desa Pandau Jaya Kecamatan Siak Hulu Kabupaten Kampar. Waktu penelitian dilaksanakan Pebruari - Juli 2018.

\section{Alat dan Bahan}

Objek yang diteliti pada penelitian ini adalah jenis-jenis burung, vegetasi sebagai habitat/tempat burung untuk beraktifitas di wilayah pedesaan, thally sheet sebagai bahan mencatat data. Peralatan yang digunakan adalah: Binokuler (teropong) dengan ukuran $30 \times 60$, untuk melihat burung dengan lebih jelas; Kamera digital SLR dengan ukuran lensa 75 - 300 mm; Alat tulis menulis; Alat perekam untuk merekam suara/ kicauan burung; Alat penunjuk waktu; Buku Panduan Lapangan Pengenalan Burung : Burung-Burung Di Jawa dan Bali (MacKinnon, 1991), BurungBurung di Sumatera dan Kalimantan (Holmes, 1999), Daftar Burung Indonesian No.2 (Sukmantoro, 2007), Burung-Burung di Sumatera, Kalimantan, Jawa dan Bali (MacKinnon, 2010), Informasi Tambahan Burung-Burung di Sumatera, Jawa, Bali dan Kalimantan (Balen, 2010), Memelihara Burung Ocehan Populer (Turut, 2010).

\section{Metode Pengumpulan Data Burung}

Seluruh data burung diambil dengan menggunakan metode titik hitung (point count) (Bibby, 2000) dengan bentuk plot bulat sirkular dengan diameter plot \pm 40 meter pada titik yang telah ditentukan. Pengambilan data dilakukan dengan mengobservasi burung di lokasi penelitian dengan mencatat seluruh data jenis burung, jumlah individu, waktu perjumpaan, perilaku dan aktivitas burung.

Pengamatan dilakukan pada pagi dan sore hari antara 06.00 - 08.00 WIB dan pukul 16.00.00 - 18.00 WIB dalam cuaca cerah/ baik, dalam jalur pengamatan yang telah ditentukan dengan waktu pengamatan setiap 20 menit. Dilakukan juga pengamatan khusus untuk burung malam (nocturnal). Khusus untuk burung malam data yang diambil adalah jenis dan jumlahnya, untuk satu kawasan. Untuk menjamin jarak pandang dan pengenalan jenis burung pengamatan dilakukan pada malam hari pukul 19.00 - 20.00 WIB dengan mengenali suaranya atau melihat langsung jenis burung tersebut.

Pencatatan jenis burung dilakukan dengan metode kombinasi langsung dan tidak langsung. Metode pencatatan secara 
langsung dilakukan dengan melihat burung (baik kasat mata maupun dengan menggunakan teropong) dengan bantuan Buku Panduan Lapangan Pengenalan Burung (Holmes, 1999; Sukmantoro 2007: MacKinnon 1991, 2010) dan secara tidak langsung dengan didasarkan pada suara burung dan sarangnya. Pada penelitian ini pengamatan dilakukan pada 2 (dua) tempat. Pemilihan lokasi ini didasarkan pada pertimbangan kondisi tempat yang mewakili kebun campuran di Desa Pandau Jaya.

Tahapan Pengamatan (Bibby 2000) : Pengamat mengamati burung pada masingmasing plot (satu kawasan terdiri atas 6 plot); Pengamat mencatat nama dan jumlah jenis yang ada disetiap plot; Pencatatan dilakukan selama interval 20 menit; Pengamat berpindah pada plot lain; Setiap plot pengamatan burung diamati sehari 2 kali pada pagi hari dan sore hari dengan 3 kali ulangan.

\section{Analisis Data}

\section{Indeks Keanekaragaman Jenis}

Untuk menentukan keanekaragaman jenis digunakan indeks keanekaragaman Shannon-Wiener dengan rumus :
$H^{\prime}=-\sum p_{i} \ln p_{i}$

Keterangan:

$H^{\prime}=$ indeks keanekaragaman Shannon

$p_{i}=\left(n_{i} / N\right)$

$n_{i}=$ jumlah individu ke- $i$

$N=$ Jumlah seluruh individu

ln = logaritma natural

Menurut Maguran (1998) dalam Rahmawaty (2006), nilai indeks keanekaragaman jenis berkisar antara 1,53,5. Nilai $<1,5$ menunjukkan keanekaragaman jenis rendah, selanjutnya nilai $1,5 \quad-\quad 3,5$ menunjukkan keanekaragaman sedang nilai > 3,5 menunjukkan keanekaragaman tinggi

\section{Indeks Kemerataan}

Untuk menentukan proporsi kelimpahan jenis yang ada digunakan indeks kemerataan (Index of Eveness) yaitu jumlah individu dari suatu jenis atau kelimpahan masing-masing jenis dalam suatu komunitas.( Setiawan 2006; Dewi 2007)

\section{$E=H^{\prime} / \ln S$}

Keterangan:

$E=$ indeks kemerataan (berkisar $0-1$ )

$H^{\prime}=$ indeks keanekaragaman Shannon

$S=$ jumlah jenis 
$\ln =$ logaritma natural

\section{Indeks Kekayaan Jenis}

Untuk menghitung kekayaan jenis pada setiap lokasi menggunakan Indeks Margalef ( Setiawan 2006) sebagai berikut :

$$
R=\frac{(S-1)}{\ln N}
$$

Keterangan :

$R=$ Indeks Kekayaan Jenis Margalef

$S=$ Jumlah Jenis

$N=$ Jumlah Individu

$\ln =$ Logaritma natural

\section{Analisis Dominansi Jenis Burung}

Analisis dominansi jenis burung digunakan untuk melihat komposisi jenis burung yang dominan, sub dominan dan jarang dalam komunitas burung yang diamati. Analisis menggunakan parameter kerapatan relatif sesuai dengan kategori yang dikemukakan oleh Jorgensen (1974), yaitu kategori burung dominan bila kerapatan relatifnya $>5 \%$, sub dominan apabila kerapatan relatifnya antara 2\% - 5\% dan jarang apabila kerapatan relatifnya < $2 \%$.

Rumus yang digunakan untuk menganalisis dominansi :

Kerapatan Jenis $(K)=\frac{\text { Jumlah suatu jenis burung }}{\text { Luas plot contoh }}$
Kerapatan Relatif $($ KR $)=\frac{\text { Kerapatan suatu jenis }}{\text { Kerapatan seluruh jenis }} \times 100 \%$

\section{Analisis Tingkat Pertemuan Jenis}

Analisis ini digunakan untuk menghitung tingkat pertemuan untuk tiap jenis burung yang ada pada lokasi penelitian, yaitu dengan cara membagi jumlah total tiap jenis burung yang tercatat dengan waktu total pengamatan dikalikan dengan sepuluh (10), sehingga dihasilkan tingkat pertemuan tiap jenis burung per sepuluh jam pengamatan. Kemudian hasil dari perhitungan tersebut dikategorikan, apakah termasuk "jarang", "tidak umum", "sering", "umum" ataupun "melimpah". Pembagian kategori tersebut menggunakan tabel tingkat pertemuan jenis burung menurut Lowen et al., (1996) dalam Bibby (2000) seperti pada Tabel 1. 
Tabel 1. Penggunaan Tingkat Pertemuan Untuk Memperlihatkan Skala Urutan Kelimpahan (Lowen et al. 1996 dalam Bibby 2000)

\section{Kategori kelimpahan (jml individu} per 10 jam pengamatan

\section{Nilai}

Kelimpahan
Skala urutan

Jarang

$0,1-2,0 \quad 2 \quad$ Tidak Umum

$2,1-10,0 \quad 3 \quad$ Sering

$10,1-40,0$

4

Umum

$>40,0$

5

Melimpah

\section{HASIL DAN PEMBAHASAN}

Jenis Burung di Kebun Campuran Desa

Pandau Jaya

\section{Lokasi pengamatan A (lokasi yang} dikelilingi oleh perumahan)

Pada lokasi ini dijumpai sebanyak 24 jenis burung yang termasuk ke dalam 13 famili. Jenis burung yang sering hadir adalah Cucak Kutilang (Pycnonotus aurigaster) sebanyak 24 individu, Perkutut Jawa (Geopelia striata) dengan jumlah individu yang dijumpai masing-masing sebanyak 22 individu dan Tekukur Biasa (Streptopelia chinensis) sebanyak 20 individu. Jenis-jenis burung di lokasi pengamatan lokasi A sebagaimana tercantum pada Tabel 2 .

Tabel 2. Jenis Burung di Lokasi Pengamatan A

\begin{tabular}{|c|c|c|c|c|}
\hline No. & Nama Lokal & Nama Ilmiah & Famili & Jumlah Individu \\
\hline 1 & Perkutut Jawa & Geopelia striata & Columbidae & 22 \\
\hline 2 & Kipasan Belang & Rhipidura javanica & Rhipiduridae & 1 \\
\hline 3 & Cucak Kutilang & Pycnonotus aurigaster & Pycnonotidae & 24 \\
\hline
\end{tabular}




\begin{tabular}{|c|c|c|c|c|}
\hline 4 & Cinenen Kelabu & Orthotomus ruficeps & Silviidae & 8 \\
\hline 5 & Prenjak Jawa & Prinia familiaris & Sylvidae & 8 \\
\hline 6 & Prenjak Coklat & Prinia polychroa & Sylvidae & 6 \\
\hline 7 & Burung Madu Polos & Antrheptes simplex & Nectariniidae & 10 \\
\hline 8 & Burung Madu Kelapa & Antrheptes malacensis & Nectariniidae & 6 \\
\hline 9 & Burung Madu Belukar & Antrheptes singalensis & Nectariniidae & 6 \\
\hline 10 & Burung Madu Sriganti & Nectarinia jagularis & Nectariniidae & 12 \\
\hline 11 & Pijantung Kecil & Arachnothera longirostra & Nectariniidae & 2 \\
\hline 12 & Tekukur Biasa & Streptopelia chinensis & Columbidae & 20 \\
\hline 13 & Bondol Peking & Lonchura punctulata & Estrildidae & 14 \\
\hline 14 & Bondol Jawa & Lonchura leucogastra & Estrildidae & 7 \\
\hline 15 & Bubut Alang-alang & Centropus bengalensis & Cuculidae & 2 \\
\hline 16 & Merbah Corok-corok & Pycnonotus simplex & Pycnonotidae & 8 \\
\hline 17 & Merbah Cerukcuk & Pycnonotus flavescens & Pycnonotidae & 15 \\
\hline 18 & Cabai Jawa & Dicacum trchileum & Dicaeidae & 5 \\
\hline 19 & Puyuh Batu & Coturnix chinensis & Phasianidae & 6 \\
\hline 20 & Kareo Padi & Amaurornis phoenicurus & Rallidae & 8 \\
\hline 21 & Kapasan Kemiri & Lalage nigra & Campephagidae & 2 \\
\hline 22 & Bentet Kelabu & Lanius schach & Laniidae & 1 \\
\hline 23 & Kucica Kampung & Copsychus saularis & Muscicapidae & 1 \\
\hline \multirow[t]{2}{*}{24} & Cabak Kota & Caprimulgus affinis & Caprimulgidae & 2 \\
\hline & & Total Indivdiu & & 196 \\
\hline
\end{tabular}




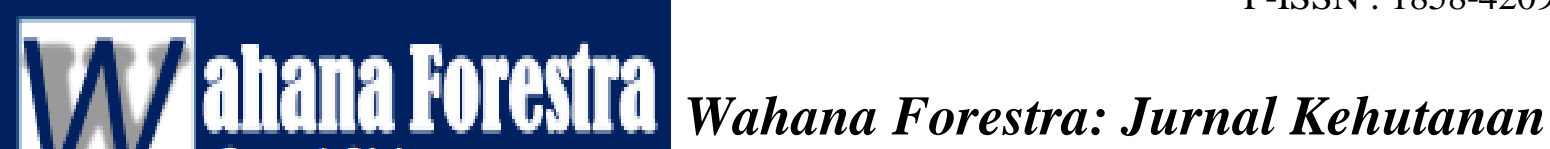 gutnal Kehutanan}

Berdasar pada Tabel 2 terdapat jenis burung yang sering terlihat di kebun campuran ini adalah Cucak Kutilang ( $P$. aurigaster). Hal ini disebabkan jenis ini selalu terlihat berkelompok paling sedikit 2 ekor, selain itu juga jenis burung ini terlihat cukup terbiasa terhadap adanya aktivitas manusia. Lokasi penelitian ini dikelilingi kompleks perumahan dan jalan raya, tetapi hal itu tidak begitu mengganngu kehadiran burung Cucak Kutilang ini. Dengan tersedianya vegetasi yang cukup sebagai tempat mencari makan dan berkembang biak serta sedikit gangguan dari pemburu burung menyebabkan jumlah individunya terus bertambah.

Selain Cucak Kutilang juga terdapat jenis-jenis burung lain yang berada di lokasi ini, meskipun jumlahnya tidak banyak. Hal ini terjadi karena burung-burung tersebut sensitif dengan aktivitas manusia di sekitar kebun campuran. Jenis-jenis burung pemakan serangga (insectivora), pemakan biji (granivora) dan penghisap nektar (nectarivora) cukup sering terlihat di kebun campuran ini. Hal ini didukung oleh ketersediaan pakan yang cukup yang dibutuhkan oleh jenis-jenis burung tersebut

\section{Lokasi pengamatan B (lokasi dipinggir perumahan)}

Pada lokasi ini dijumpai sebanyak 20 jenis burung yang termasuk ke dalam 11 famili. Jenis burung yang sering hadir adalah Cucak Kutilang (Pycnonotus aurigaster) dan Bondol Peking (Lonchura punctulata) masing-masimg sebanyak 20 individu dan Perkutut Jawa (Geopelia striata) sebanyak 15 individu sebagaimana tercantum pada Tabel 3.

Tabel 3. Jenis Burung di Lokasi Pengamatan B

\begin{tabular}{clllc}
\hline No. & Nama Lokal & Nama Ilmiah & Famili & Jumlah Individu \\
\hline 1 & Perkutut Jawa & Geopelia striata & Columbidae & 15 \\
\hline 2 & Cucak Kutilang & Pycnonotus aurigaster & Pycnonotidae & 20 \\
\hline 3 & Cinenen Kelabu & Orthotomus ruficeps & Silviidae & 4 \\
\hline 4 & Prenjak Jawa & Prinia familiaris & Sylvidae & 8 \\
\hline 5 & Prenjak Coklat & Prinia polychroa & Sylvidae & 8 \\
\hline 6 & Burung Madu Polos & Antrheptes simplex & Nectariniidae & 6 \\
\hline 7 & Burung Madu Kelapa & Antrheptes malacensis & Nectariniidae & 3 \\
\hline 8 & Burung Madu Belukar & Antrheptes singalensis & Nectariniidae & 6 \\
\hline 9 & Burung Madu Sriganti & Nectarinia jagularis & Nectariniidae & 9
\end{tabular}




\begin{tabular}{clllc}
10 & Tekukur Biasa & Streptopelia chinensis & Columbidae & 14 \\
\hline 11 & Bondol Peking & Lonchura punctulata & Estrildidae & 20 \\
\hline 12 & Bondol Jawa & Lonchura leucogastra & Estrildidae & 10 \\
\hline 13 & Bubut Alang-alang & Centropus bengalensis & Cuculidae & 4 \\
\hline 14 & Merbah Belukar & Pycnonotus plumosus & Pycnonotidae & 8 \\
\hline 15 & Merbah Cerukcuk & Pycnonotus flavescens & Pycnonotidae & 12 \\
\hline 16 & Cabai Jawa & Dicacum trchileum & Dicaeidae & 4 \\
\hline 17 & Puyuh Batu & Coturnix chinensis & Phasianidae & 6 \\
\hline 18 & Kareo Padi & Amaurornis phoenicurus & Rallidae & 10 \\
\hline 19 & Cekakak Sungai & Todirhamphus chloris & Alcedinidae & 1 \\
\hline 20 & Kerak Ungu & Acridotheres tristis & Sturnidae & 2 \\
\hline & & Total Indivdiu & & $\mathbf{1 7 0}$ \\
\hline & Sumber : Data Olahan, 2018. & &
\end{tabular}

Berdasar pada Tabel 3 terdapat jenis burung yang sering terlihat di kebun campuran ini sama dengan di Kebun Campuran A yaitu Cucak Kutilang ( $P$. aurigaster). Jenis burung ini sering terlihat berkelompok, selain itu juga jenis burung ini terlihat tidak terganggu terhadap adanya aktivitas manusia di sekitarnya. Lokasi penelitian ini dikelilingi perumahan penduduk, tetapi hal itu tidak begitu mengganngu kehadiran burung Cucak Kutilang ini.

Selain Cucak Kutilang juga terdapat jenis-jenis burung lain yang berada di lokasi ini, meskipun jumlahnya tidak banyak seperti pada lokasi Kebun Campuran A. Sama seperti di Kebun Campuran A jenis-jenis burung pemakan serangga (insectivora), pemakan biji (granivora) dan penghisap nektar (nectarivora) cukup sering terlihat di kebun campuran ini.

\section{Jenis burung di seluruh lokasi pengamatan}

Dari hasil pengumpulan data pengamatan jenis burung di 2 lokasi dijumpai sebanyak 12 jenis burung yang terdiri dari 7 famili. Jenis burung yang sering hadir adalah Cucak Kutilang (Pycnonotus aurigaster) sebanyak 20 individu, Bondol Peking (Lonchura punctulata) sebanyak 14 individu dan Perkutut Jawa (Geopelia striata) sebanyak 10 individu sebagaimana tercantum pada Tabel 4. 
Tabel 4. Jenis Burung di Seluruh Lokasi Pengamatan

\begin{tabular}{|c|c|c|c|c|}
\hline No. & Nama Lokal & Nama Ilmiah & Famili & Jumlah Individu \\
\hline 1 & Bentet Kelabu & Lanius schach & Laniidae & 1 \\
\hline 2 & Bondol Jawa & Lonchura leucogastra & Estrildidae & 17 \\
\hline 3 & Bondol Peking & Lonchura punctulata & Estrildidae & 34 \\
\hline 4 & Bubut Alang-alang & Centropus bengalensis & Cuculidae & 6 \\
\hline 5 & Burung Madu Belukar & Antrheptes singalensis & Nectariniidae & 12 \\
\hline 6 & Burung Madu Kelapa & Antrheptes malacensis & Nectariniidae & 9 \\
\hline 7 & Burung Madu Polos & Antrheptes simplex & Nectariniidae & 16 \\
\hline 8 & Burung Madu Sriganti & Nectarinia jagularis & Nectariniidae & 21 \\
\hline 9 & Cabai Jawa & Dicacum trchileum & Dicaeidae & 9 \\
\hline 10 & Cabak Kota & Caprimulgus affinis & Caprimulgidae & 2 \\
\hline 11 & Cekakak Sungai & Todirhamphus chloris & Alcedinidae & 1 \\
\hline 12 & Cinenen Kelabu & Orthotomus ruficeps & Silviidae & 12 \\
\hline 13 & Cucak Kutilang & Pycnonotus aurigaster & Pycnonotidae & 44 \\
\hline 14 & Kapasan Kemiri & Lalage nigra & Campephagidae & 2 \\
\hline 15 & Kareo Padi & Amaurornis phoenicurus & Rallidae & 18 \\
\hline 16 & Kerak Ungu & Acridotheres tristis & Sturnidae & 2 \\
\hline 17 & Kipasan Belang & Rhipidura javanica & Rhipiduridae & 1 \\
\hline 18 & Kucica Kampung & Copsychus saularis & Muscicapidae & 1 \\
\hline 19 & Merbah Belukar & Pycnonotus plumosus & Pycnonotidae & 8 \\
\hline 20 & Merbah Cerukcuk & Pycnonotus flavescens & Pycnonotidae & 27 \\
\hline 21 & Merbah Corok-corok & Pycnonotus simplex & Pycnonotidae & 8 \\
\hline 22 & Perkutut Jawa & Geopelia striata & Columbidae & 37 \\
\hline 23 & Pijantung Kecil & Arachnothera longirostra & Nectariniidae & 2 \\
\hline 24 & Prenjak Coklat & Prinia polychroa & Sylvidae & 14 \\
\hline 25 & Prenjak Jawa & Prinia familiaris & Sylvidae & 16 \\
\hline 26 & Puyuh Batu & Coturnix chinensis & Phasianidae & 12 \\
\hline 27 & Tekukur Biasa & Streptopelia chinensis & Columbidae & 34 \\
\hline \multicolumn{4}{|c|}{ Total Indivdiu } & 366 \\
\hline
\end{tabular}

Sumber : Data Olahan, 2018. 
Berdasarkan Tabel 4 diatas terlihat bahwa jumlah famili burung di 2 lokasi pengamatan adalah 15 famili yang paling banyak terdapat pada famili Nectariniidae sebanyak 5 jenis yaitu Burung Madu Sriganti (Nectarinia jagularis), Burung Madu Kelapa (Antrheptes malacensis), Burung Madu Belukar Burung (Antrheptes singalensis), Madu Polos (Antrheptes simplex) dan Pijantung Kecil (Arachnothera longirostra), di ikuti oleh famili Pycnonotidae sebanyak 4 jenis yaitu Cucak Kutilang (Pycnonotus aurigaster) dan Merbah Cerukcuk (Pycnonotus flavescens), famili Sylvidae sebanyak 3 jenis yaitu Cinenen Kelabu (Orthotomus ruficeps) dan Perenjak Jawa (Prinia familiars), sedangkan untuk famili yang jenisnya satu adalah famili Estrildidae yaitu Bondol Peking (Lonchura punctulata), famili Columbidae yaitu Perkutut Jawa (Geopelia striata), famili Sylvidae yaitu Perenjak Jawa (Prinia familiaris), famili Dicaeidae yaitu Cabai Jawa (Dicacum trchileum) dan famili Caprimulgidae yaitu Cabak Kota (Caprimulgus affinis)

Penyebab banyak jumlah individu Cucak Kutilang (Pycnonotus aurigaster), Bondol Peking (Lonchura punctulata),
Perkutut Jawa (Geopelia striata) dan Merbah Cerukcuk (Pycnonotus flavescens) adalah ketersediaan makanan yang mencukupi, pemenuhan habitat oleh vegetasi yang memungkinkan jenis burung ini untuk hidup dan berkembang biak. Jenis-jenis burung diatas merupakan jenis burung pemakan buah, serangga dan bijibijian sebagai pakan utama. Pada beberapa pengamatan burung ini juga terlihat memakan ulat, sari madu bunga atau menyambar serangga kecil yang terbang. Jenis burung ini juga dalam pergerakannya terlihat aktif di semua titik pengamatan yang ada di 2 lokasi pengamatan. Beberapa jenis burung yang terdapat di kebun campuran Desa Pandau Jaya sebagaimana terdapat pada Gambar 1. 


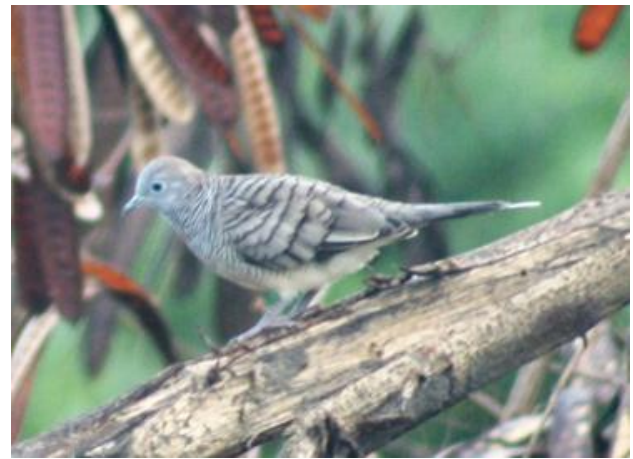

(a)

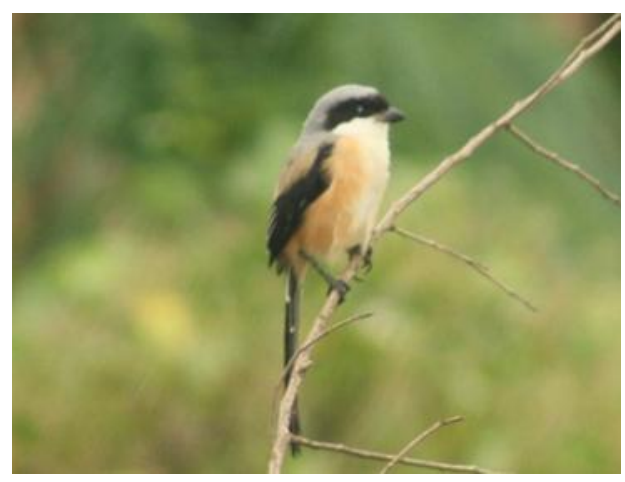

(c)

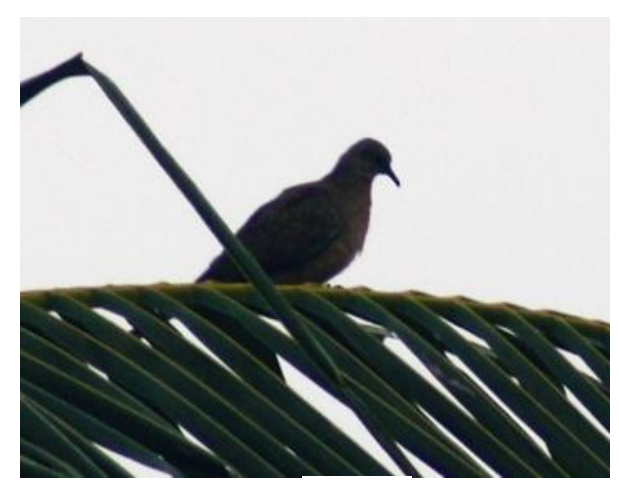

(b)

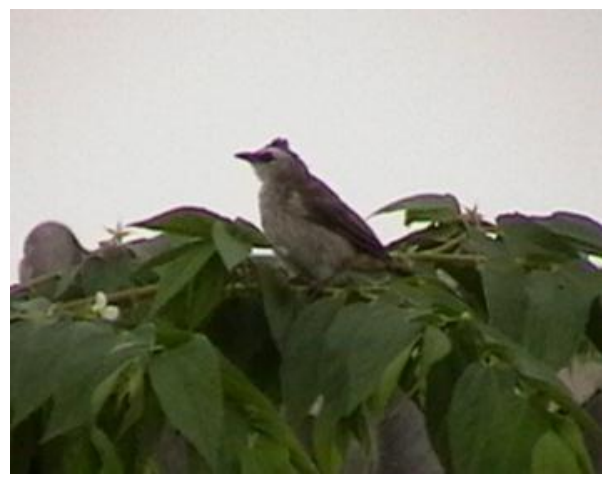

(d)

Gambar 1. Jenis-Jenis Burung Di Lingkungan Kompleks Perumahan Pandau Permai dan Mahang Raya; (a) Perkutut Jawa, (b) Tekukur Biasa, (c) Bentet Kelabu, (d) Merbah Cerukcuk.

Jumlah individu, jenis dan famili tiap lokasi pengamatan untuk keseluruhan di dominasi oleh lokasi pengamatan A dengan jumlah 196 individu, 24 jenis dan 13 famili sedangkan untuk lokasi B dengan jumlah 170 individu, 20 jenis dan 11 famili. Hal tersebut menunjukkan bahwa lokasi pengamatan di lokasi A jumlah individu dan jenis burung lebih tinggi dibandingkan pada lokasi B namun untuk jumlah familinya hampir sama. Hal ini disebabkan di lokasi pengamatan A vegetasinya cukup banyak dan beragam apabila dibandingkan dengan lokasi B

Di samping kondisi vegetasinya lebih banyak di lokasi A juga menjadi tempat penyediaan kebutuhan hidup bagi burung cukup tersedia. Hal ini terjadi karena lokasi A sudah cukup lama dikerjakan/digunakan, sehingga vegetasinya terutama pohon sudah cukup tua dan beragam. Di lokasi B jumlah vegetasi 
relative muda dan sedikit karena lokasi ini didominasi semak belukar.

\section{Keanekaragaman Jenis burung di Kebun} Campuran

Setelah dilakukan analisis data terhadap jenis burung diketahui indeks keanekaragaman jenis burung tertinggi terdapat pada lokasi lokasi A $(2,87)$ dan di lokasi B (2,80). Namun indeks keanekaragaman jenis secara keseluruhan mencapai 2,90.

Nilai indeks keanekaragaman jenis pada semua lokasi pengamatan menunjukkan tingkat keanekaragaman jenis yang sedang (nilai H' 1.5 - 3.5), cukup tingginya indeks keanekaragaman jenis pada lokasi A disebabkan pada lokasi tersebut merupakan kawasan kebun campuran yang relatif lama dikerjakan. Selain itu kawasan lokasi A juga memiliki vegetasi yang lebih beragam dibandingkan dengan lokasi lainnya yang masih dibilang rendah dan masih kecil jumlahnya. Selain itu kondisi vegetasi yang masih sedikit memiliki pengaruh dalam pemenuhan kebutuhan makan bagi burung, jenis burung yang beragam mengandung arti bahwa vegetasi yang ada mampu menyediakan makanan yang cukup dengan kelas yang beragam dalam memproduksi buah, daun muda untuk makanan serangga dan sebagainya. Kenyataan ini mengakibatkan persaiangan dalam perebutan makanan, ruang serta keamanan tidak terpenuhi sehingga menyebabkan jumlah dan jenis burung tidak banyak dan Indeks keanekaragaman menjadi rendah. Hal ini juga sejalan dengan hasil penelitian Hadinoto, dkk (2012) di Hutan Kota Pekanbaru bahwa keanekaragaman jenis burung berkorelasi positif dengan keanekaragaman jenis pohon. Makin tinggi keanekaragaman jenis pohon, keanekeragaman jenis burung yang ditemui makin tinggi.

Pohon sebagai komponen habitat burung, dapat berfungsi sebagai cover (tempat berlindung dari cuaca dan predator, bersarang, bermain beristirahat). Selain menyediakan bagian-bagian pohon (daun, bunga, dan buah) suatu pohon dapat berfungsi sebagai habitat bagi berbagai jenis organisme lain yang merupakan makanan tersedia bagi burung seperti serangga. Menurut Farimansyah (1981) dalam Wisnu Budi (2009) keanekaragaman jenis vegetasi yang tinggi dapat merupakan 
tempat sumber pakan, tempat berlindung maupun tempat bersarang dari jenis-jenis burung. Keanekaragaman jenis burung dipengaruhi oleh banyak faktor, diantaranya kelimpahan epifit, kelimpahan buahbuahan, keterbukaan lantai hutan dan komposisi jenis pohon (Orians, 1969 dalam Wisnubudi, 2009).

Indeks struktur komunitas burung dimasing-masing lokasi relatif sama, sebagaimana tercantum pada Tabel 5 .

Tabel 5. Indeks Struktur Komunitas Burung di Masing-Masing Lokasi

\begin{tabular}{lcccccc}
\hline \multicolumn{1}{c}{ Lokasi } & Jenis & Individu & Famili & $\mathbf{H}^{\prime}$ & $\mathbf{E}$ & $\mathbf{R}$ \\
\hline Lokasi A & 24 & 196 & 13 & 2,87 & 0,90 & 4,36 \\
\hline Lokasi B & 20 & 170 & 11 & 2,80 & 0,94 & 3,70 \\
\hline Sumber : Data Olahan, 2018. & & & & &
\end{tabular}

Data Tabel 5 menunjukkan bahwa indeks kekayaan untuk lokasi A dengan lokasi B relatif sama. Indeks keanekaragaman jenis lokasi A lebih tinggi dari lokasi B. Indek Kemerataan (E) digunakan sebagai indikator adanya gejala dominasi diantara setiap jenis dalam suatu komunitas. Apabila setiap jenis memiliki jumlah individu yang sama, maka komunitas tersebut mempunyai nilai "EVENNESS" maksimum. Sebaliknya, bila nilai kemerataan ini kecil, maka dalam komunitas tersebut terdapat jenis dominan, sub-dominan dan jenis yang terdominasi, maka komunitas tersebut memiliki "EVENNES" minimum. Dari hasil analisa data jenis burung diketahui kemerataan jenis tertinggi terdapat pada lokasi pengamatan lokasi B yaitu 0.94 dan lokasi A sebesar 0,90. Kekayaan jenis (R) burung tertinggi terdapat pada lokasi pengamatan lokasi A (4,36) dan di lokasi B (3.70), apabila dihitung secara keseluruhan, maka kekayaan jenis (R) burung adalah sebesar 4,40 .

\section{Kerapatan, Dominansi dan Skala Urutan Burung di Kebun Campuran}

Berdasar hasil pengamatan terdapat 2 jenis burung yang memiliki nilai Kerapatan Relatif (KR) tertinggi yaitu Cucak Kutilang (Pycnonotus aurigaster) 
yaitu 12,20\% dan Perkutut Jawa (Geopelia striata) yaitu $10,11 \%$ dan nilai KR yang terkecil adalah Bentet Kelabu (Lanius schach), Cekakak Sungai (Todirhamphus chloris), Kipasan Belang (Rhipidura javanica) dan Kucica Kampung (Copsychus saularis) yaitu $0,27 \%$. Hal ini dipengaruhi oleh kondisi habitat yang cukup baik dan perkembangbiakan jenis ini cukup baik serta minimnya pemangsa burung yang memungkinkan kedua jenis tersebut nilai KR cukup tinggi. Beberapa jenis burung memiliki nilai dominansi tinggi dan memiliki nilai skala urutan umum, sebagaimana tercantum pada Tabel 6 berikut .

Tabel 6. Kerapatan, Dominansi dan Skala Urutan Burung di Kebun Campuran

\begin{tabular}{|c|c|c|c|c|c|c|c|c|}
\hline No. & Nama Daerah & Nama Ilmiah & $\mathrm{K}$ & $\begin{array}{l}\mathrm{KR} \\
(\%)\end{array}$ & Dominansi & $\begin{array}{c}\text { Kateg } \\
\text { ori } \\
\text { Kelim } \\
\text { pahan }\end{array}$ & $\begin{array}{l}\text { Nila } \\
\text { i } \\
\text { Keli } \\
\text { mpa } \\
\text { han }\end{array}$ & $\begin{array}{l}\text { Skala } \\
\text { Urutan }\end{array}$ \\
\hline 1 & Bentet Kelabu & Lanius schach & 0.66 & 0.27 & Jarang & 0.83 & 1 & Jarang \\
\hline 2 & Bondol Jawa & Lonchura leucogastra & 11.27 & 4.64 & $\begin{array}{c}\text { Sub } \\
\text { Dominan }\end{array}$ & 14.17 & 4 & Umum \\
\hline 3 & Bondol Peking & Lonchura punctulata & 22.55 & 9.29 & Dominan & 28.33 & 4 & Umum \\
\hline 4 & Bubut Alang-alang & Centropus bengalensis & 3.98 & 1.64 & Jarang & 5.00 & 3 & Sering \\
\hline 5 & Burung Madu Belukar & Antrheptes singalensis & 7.96 & 3.28 & $\begin{array}{c}\text { Sub } \\
\text { Dominan }\end{array}$ & 10.00 & 4 & Umum \\
\hline 6 & Burung Madu Kelapa & Antrheptes malacensis & 5.97 & 2.46 & $\begin{array}{c}\text { Sub } \\
\text { Dominan }\end{array}$ & 7.50 & 3 & Sering \\
\hline 7 & Burung Madu Polos & Antrheptes simplex & 10.61 & 4.37 & $\begin{array}{c}\text { Sub } \\
\text { Dominan }\end{array}$ & 13.33 & 4 & Umum \\
\hline 8 & Burung Madu Sriganti & Nectarinia jagularis & 13.93 & 5.74 & Dominan & 17.50 & 4 & Umum \\
\hline 9 & Cabai Jawa & Dicacum trchileum & 5.97 & 2.46 & $\begin{array}{c}\text { Sub } \\
\text { Dominan }\end{array}$ & 7.50 & 3 & Sering \\
\hline 10 & Cabak Kota & Caprimulgus affinis & 1.33 & 0.55 & Jarang & 1.67 & 2 & $\begin{array}{l}\text { Tidak } \\
\text { Umum }\end{array}$ \\
\hline 11 & Cekakak Sungai & Todirhamphus chloris & 0.66 & 0.27 & Jarang & 0.83 & 1 & Jarang \\
\hline 12 & Cinenen Kelabu & Orthotomus ruficeps & 7.96 & 3.28 & $\begin{array}{c}\text { Sub } \\
\text { Dominan }\end{array}$ & 10.00 & 4 & Umum \\
\hline 13 & Cucak Kutilang & Pycnonotus aurigaster & 29.18 & 12.02 & Dominan & 36.67 & 4 & Umum \\
\hline 14 & Kapasan Kemiri & Lalage nigra & 1.33 & 0.55 & Jarang & 1.67 & 2 & Tidak \\
\hline
\end{tabular}




\begin{tabular}{|c|c|c|c|c|c|c|c|c|}
\hline No. & Nama Daerah & Nama Ilmiah & $\mathrm{K}$ & $\begin{array}{l}\mathrm{KR} \\
(\%)\end{array}$ & Dominansi & $\begin{array}{c}\text { Kateg } \\
\text { ori } \\
\text { Kelim } \\
\text { pahan }\end{array}$ & $\begin{array}{l}\text { Nila } \\
\text { i } \\
\text { Keli } \\
\text { mpa } \\
\text { han }\end{array}$ & $\begin{array}{l}\text { Skala } \\
\text { Urutan }\end{array}$ \\
\hline & & & & & & & & Umum \\
\hline 15 & Kareo Padi & Amaurornis phoenicurus & 11.94 & 4.92 & $\begin{array}{c}\text { Sub } \\
\text { Dominan }\end{array}$ & 15.00 & 4 & Umum \\
\hline 16 & Kerak Ungu & Acridotheres tristis & 1.33 & 0.55 & Jarang & 1.67 & 2 & $\begin{array}{l}\text { Tidak } \\
\text { Umum }\end{array}$ \\
\hline 17 & Kipasan Belang & Rhipidura javanica & 0.66 & 0.27 & Jarang & 0.83 & 1 & Jarang \\
\hline 18 & Kucica Kampung & Copsychus saularis & 0.66 & 0.27 & Jarang & 0.83 & 1 & Jarang \\
\hline 19 & Merbah Belukar & Pycnonotus plumosus & 5.31 & 2.19 & $\begin{array}{c}\text { Sub } \\
\text { Dominan }\end{array}$ & 6.67 & 3 & Sering \\
\hline 20 & Merbah Cerukcuk & Pycnonotus flavescens & 17.90 & 7.38 & Dominan & 22.50 & 4 & Umum \\
\hline 21 & Merbah Corok-corok & Pycnonotus simplex & 5.31 & 2.19 & $\begin{array}{c}\text { Sub } \\
\text { Dominan }\end{array}$ & 6.67 & 3 & Sering \\
\hline 22 & Perkutut Jawa & Geopelia striata & 24.54 & 10.11 & Dominan & 30.83 & 4 & Umum \\
\hline 23 & Pijantung Kecil & $\begin{array}{l}\text { Arachnothera } \\
\text { longirostra }\end{array}$ & 1.33 & 0.55 & Jarang & 1.67 & 2 & $\begin{array}{l}\text { Tidak } \\
\text { Umum }\end{array}$ \\
\hline 24 & Prenjak Coklat & Prinia polychroa & 9.28 & 3.83 & $\begin{array}{c}\text { Sub } \\
\text { Dominan }\end{array}$ & 11.67 & 4 & Umum \\
\hline 25 & Prenjak Jawa & Prinia familiaris & 10.61 & 4.37 & $\begin{array}{c}\text { Sub } \\
\text { Dominan }\end{array}$ & 13.33 & 4 & Umum \\
\hline 26 & Puyuh Batu & Coturnix chinensis & 7.96 & 3.28 & $\begin{array}{c}\text { Sub } \\
\text { Dominan }\end{array}$ & 10.00 & 4 & Umum \\
\hline 27 & Tekukur Biasa & Streptopelia chinensis & 22.55 & 9.29 & Dominan & 28.33 & 4 & Umum \\
\hline
\end{tabular}

Berdasar Tabel 6 di atas terdapat 6 jenis burung yang memiliki nilai dominansi tinggi dan terdapat 14 jenis burung yang memiliki nilai skala urutan tinggi. Hal itu didukung oleh kondisi habitat berupa kebun campuran yang cukup memadai bagi burung untuk dapat hidup dan berkembang biak dengan baik.

\section{Vegetasi Sebagai Sumber Pakan Burung}

Tipe vegetasi pada lokasi pengamatan burung bervariasi antara berupa pohon, herba, bunga-bungaan, tanaman hortikultura dan rumputrumputan sebagaimana tercantum pada Tabel 7. 
Tabel 7. Jenis Vegetasi Sebagai Sumber Pakan Burung

\begin{tabular}{|c|c|c|c|c|}
\hline No & Nama Jenis & Jenis Vegetasi & Bagian yang dimakan burung & Keterangan \\
\hline 1 & Mahoni & Pohon & Serangga, sari madu bunga & \multirow{24}{*}{$\begin{array}{l}\text { Selain untuk } \\
\text { mencari } \\
\text { makan, } \\
\text { vegetasi juga } \\
\text { dijadikan } \\
\text { sebagai tempat } \\
\text { berlindung dan } \\
\text { berkembang } \\
\text { biak }\end{array}$} \\
\hline 2 & Jengkol & Pohon & Serangga, sari madu bunga & \\
\hline 3 & Nangka & Pohon & Buah, serangga, sari madu bunga & \\
\hline 4 & Jambu Air & Pohon & Buah, serangga, sari madu bunga & \\
\hline 5 & Akasia mangium & Pohon & Biji, serangga, sari madu bunga & \\
\hline 6 & Karet & Pohon & Serangga, sari madu bunga & \\
\hline 7 & Matoa & Pohon & Buah, serangga, sari madu bunga & \\
\hline 8 & Salam & Pohon & Buah, serangga, sari madu bunga & \\
\hline 9 & Angsana & Pohon & Buah, serangga, sari madu bunga & \\
\hline 10 & Mangga & Pohon & Buah, serangga, sari madu bunga & \\
\hline 11 & Sukun & Pohon & Buah, serangga, sari madu bunga & \\
\hline 12 & Rambutan & Pohon & Buah, serangga, sari madu bunga & \\
\hline 13 & Lengkeng & Pohon & Buah, serangga, sari madu bunga & \\
\hline 14 & Belimbing & Pohon & Buah, serangga, sari madu bunga & \\
\hline 15 & Sengon & Pohon & Biji, serangga, sari madu bunga & \\
\hline 16 & Kersen & Pohon & Buah, serangga, sari madu bunga & \\
\hline 17 & Lamtoro & Pohon & Biji, serangga, sari madu bunga & \\
\hline 18 & Beringin & Pohon & Buah, serangga, sari madu bunga & \\
\hline 19 & Ketapang & Pohon & Serangga, sari madu bunga & \\
\hline 20 & Mahang & Pohon & Serangga, sari madu bunga & \\
\hline 21 & Kelapa Sawit & Palem & Buah, serangga, sari madu bunga & \\
\hline 22 & Kelapa & Palem & Serangga, sari madu bunga & \\
\hline 23 & Pinang & Palem & Serangga, sari madu bunga & \\
\hline 24 & Palem-paleman & Palem & Serangga, sari madu bunga & \\
\hline 25 & Ubi Kayu & Hortikultura & Serangga, sari madu bunga & \\
\hline 26 & Ubi Rambat & Hortikultura & Serangga, sari madu bunga & Tempat \\
\hline 27 & Jagung & Hortikultura & Serangga, sari madu bunga & mencari \\
\hline 28 & Talas & Hortikultura & Serangga, sari madu bunga & makan, \\
\hline 29 & Terong & Hortikultura & Serangga, sari madu bunga & \\
\hline 30 & Cabe & Hortikultura & Serangga, sari madu bunga & \\
\hline
\end{tabular}




\begin{tabular}{|c|c|c|c|c|}
\hline No & Nama Jenis & Jenis Vegetasi & Bagian yang dimakan burung & Keterangan \\
\hline 31 & Tekokak & Hortikultura & Serangga, sari madu bunga & \\
\hline 32 & Lengkuas & Hortikultura & Serangga, sari madu bunga & \\
\hline 33 & Tebu & Hortikultura & Serangga, sari madu bunga & \\
\hline 34 & Kacang Panjang & Hortikultura & Serangga, sari madu bunga & \\
\hline 35 & Pisang & Hortikultura & Buah, serangga, sari madu bunga & \\
\hline 36 & Pepaya & Hortikultura & Buah, serangga, sari madu bunga & \\
\hline 37 & Bunga-bungaan & Herba & Buah, serangga, sari madu bunga & \\
\hline 38 & Rumput-rumputan & Rumput & Biji, serangga, sari madu bunga & \\
\hline
\end{tabular}

Berdasar pada Tabel 7 terlihat bahwa vegetasinya di dominasi oleh jenis kayukayuan. Jenis-jenis ini selain untuk tempat mencari makan, vegetasi ini juga dijadikan sebagai tempat berlindung dan berkembang biak serta aktivitas lainnya. Sedangkan untuk jenis hortikultura dan herba selain sebagai tempat mencarai makan, juga kadang kala dijadikan sebagai tempat berlindung/bersembunyi dari gangguan musuh.

\section{KESIMPULAN DAN SARAN}

\section{a. Kesimpulan}

Setelah dilakukan penelitian tentang Keanekaragaman Jenis Burung di kebun campuran Desa Pandau Jaya dapat disimpulkan sebagai berikut :

1. Ditemukan sebanyak 27 jenis burung yang terdiri dari 15 famili. Jenis burung yang sering hadir adalah Cucak Kutilang (Pycnonotus aurigaster) sebanyak 20 individu, Bondol Peking (Lonchura punctulata) 14 individu dan Perkutut Jawa (Geopelia striata) 10 individu. Keanekaragaman jenis burung (H') masih relatif sedang dengan nilai 2,90, sedangkan Indeks Kemerataan (E) sebesar 0,88 dan Indeks Kekayaan (R) sebesar 4,40.

2. Jenis vegetasi sebagai sumber pakan burung antara lain : Mahoni, Jengkol, Nangka, Jambu Air, Akasia mangium, Karet, Matoa, Salam, Angsana, Mangga, Sukun, Rambutan, Lengkeng, Belimbing, Sengon, Kersen, Lamtoro, Beringin, Ketapang, Mahang, Kelapa Sawit, Kelapa, Pinang, Palem-paleman, Ubi Kayu, Ubi Rambat, Jagung, Talas, Terong, Cabe, Tekokak, Lengkuas, 
Tebu, Kacang Panjang, Pisang, Pepaya,

Bunga-bungaan. Rumput-rumputan.

\section{b. Saran}

Saran yang dapat diberikan dalam penelitian burung sebagai berikut :

1. Agar dapat dilakukan monitoring secara berkala untuk menghindari terjadinya kepunahan terhadap burung pada berbagai tipe penggunaan lahan di Desa Pandau Jaya.

2. Diperlukan studi mengenai kehidupan burung, baik mengenai biologi maupun ekologinya meliputi populasi, habitat serta lingkungan yang ada.

\section{DAFTAR PUSTAKA}

Alikodra, HS. 2002. Pengelolaan Satwa Liar Jilid 1. Yayasan Penerbit Fakultas Kehutanan IPB. Bogor.

Beehler, BM., TK. Pratt dan DA. Zimmerman. 2001. Burung-burung di Kawasan Papua. Puslitbang Biologi LIPI. Bogor

Bibby, C., M. Jones, dan S. Marsden. $2000 . \quad$ Teknik-teknik Ekspedisi Lapangan Survei Burung. SMKG Mardi Yuana. Bogor
Hadinoto. A. Mulyadi, YI. Siregar. 2012. Keanekragaman Jenis Burung di Hutan Kota Pekanbaru. Jurnal Ilmu Lingkungan. Vol. 6 (1) : 2542

Hadinoto, E.Suhesti. 2017. Species Diversity and Bird Feed in Residential Complex. Di dalam: International Conference on Environment and Technology (IC-Tech). IOP Conf. Series: Earth and Environmental Science 97 (2017) 012001

Hernowo, JB. 1989. Suatu Tinjauan terhadap Keanekaragaman Jenis Burung dan Peranannya di Hutan Lindung Bukit Suharto, Kalimantan Timur. Media Konservasi. Vol.II (2), Januari 1989. Jurusan Konservasi Sumberdaya Hutan, Fakultas Kehutanan IPB. Bogor.

Holmes, D., dan S. Nash. 1999. Burungburung di Sumatera dan Kalimantan. Puslitbang Biologi - LIPI. Bogor

MacKinnon, J., K. Philip dan V. Balen. 2010. Seri panduan Lapangan Burung-Burung Sumatera, Kalimantan, Jawa dan Bali. Puslitbang Biologi - LIPI. Bogor

Nandika D. 2005. Hutan bagi ketahanan nasional. Universitas Muhammadiyah Surakarta. 
Odum, EP. 1998. Dasar-Dasar Ekologi. 1998. Gajah Mada

University Prees Yogyakarta

Rusmendro, H. 2009. Perbandingan Keanekaragaman Burung Pada Pagi dan Sore Hari Di Empat Tipe Habitat Di Wilayah Pangandaran, Jawa Barat. Vis Vitalis, Vol. 02 No. 1, Maret 2009. Fakultas Biologi Universitas Nasional, Jakarta

Shannaz, J., P.jepson dan Rudyanto. 1995. Burung-Burung Terancam Punah di Indonesia. PHPA/BirdLife International-Indonesia Programe. Bogor

Soeratmo, FG. 1979. Konservasi Alam dan Pengelolaan Margasatwa Bagian II (Tingkah Laku Margasatwa). Sekolah Pasca Sarjana Institut Pertanian Bogor. Bogor.

Widodo, W. 2006. Kemelimpahan dan Sumber Pakan Burungburung di Taman Nasional Manusela, Seram, Maluku Tengah. Biodiversitas 56 Vol. 7, No. 1, Januari 2006. Pusat Penelitan Biologi, Lembaga Ilmu Pengetahuan Indonesia (LIPI), CibinongBogor. 